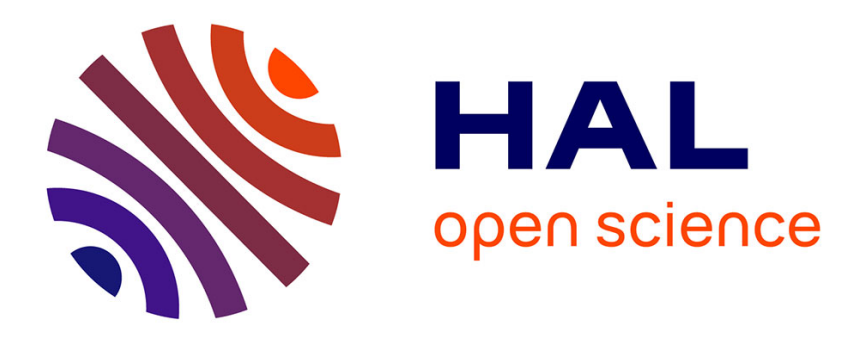

\title{
Effect of traffic stress on cool-season turfgrass under a Mediterranean climate
}

\author{
P. Martiniello
}

\section{To cite this version:}

P. Martiniello. Effect of traffic stress on cool-season turfgrass under a Mediterranean climate. Agronomy for Sustainable Development, 2007, 27 (4), pp.293-301. hal-00886344

\section{HAL Id: hal-00886344 \\ https://hal.science/hal-00886344}

Submitted on 1 Jan 2007

HAL is a multi-disciplinary open access archive for the deposit and dissemination of scientific research documents, whether they are published or not. The documents may come from teaching and research institutions in France or abroad, or from public or private research centers.
L'archive ouverte pluridisciplinaire HAL, est destinée au dépôt et à la diffusion de documents scientifiques de niveau recherche, publiés ou non, émanant des établissements d'enseignement et de recherche français ou étrangers, des laboratoires publics ou privés. 


\title{
Effect of traffic stress on cool-season turfgrass under a Mediterranean climate
}

\author{
P. MARTINIELLO* \\ CRA Istituto Sperimentale Colture Foraggere, Via Napoli 52, 71100 - Foggia, Italy
}

(Accepted 10 May 2007)

\begin{abstract}
Cool-season turfgrass for sporting use is an agronomic cultivation whose green surface is used for professional activities. On ecological grounds, turfgrass in towns is a system that can reduce atmospheric pollution, e.g. by $\mathrm{CO}_{2}$ sequestration. Here, I studied the impact of traffic on turf quality traits of turfgrass. The experiment, established in Southern Italy in the years 1999 to 2004, evaluated the impact of 2 levels of traffic stress on 3 types of turfgrass binary blends made by cultivars of tall fescue, Kentucky bluegrass, perennial ryegrass and bermudagrass species. Grasses were grown on 4 different substrates established by a mix of soil sand at 2 fertilization levels of 100 and $200 \mathrm{~N}$ units $\mathrm{kg} \mathrm{h}^{-1} \mathrm{yr}^{-1}$. I evaluated the effect of the impact on three turfgrass qualitative traits, visually assessed using rating scores from 1 to 9. The lowest score values of turf quality, color and cover traits were, respectively, 5.6, 5.7 and 5.8 recorded for blend Kentucky bluegrass and perennial ryegrass under United States Golf Association sandy soil substrate, using $200 \mathrm{~N}$ fertilizer units and a high level of traffic stress. The highest score was 7.1 for turf quality and color and 8.0 for cover traits assessed for autochthonous soil substrate under $200 \mathrm{~N}$ fertilizer units and the second level of traffic stress. Furthermore, the $200 \mathrm{~N}$ units increased all the qualitative characteristics of turf lawn. The turfgrass growing on $65-70 \%$ sand substrate with $100 \mathrm{~N}$ units fertilizer and a high level of traffic stress was an ecological green structure able to sustain the physiological process for reducing pollution in the atmosphere.
\end{abstract}

binary mixture blends / nitrogen fertilization; substrates / traffic wear stress / turfgrass quality

\section{INTRODUCTION}

Cool-season turfgrass qualitative characteristics of the green turf structures used for competitive sports activities such as American and European football, golf, baseball and softball are related to the soil properties of the substrate, agronomic practices of management, grass mixture blends and traffic stress imposed during turfgrass wear (Beard, 1973; Canaway, 1976; Waddington et al., 1992; Shearman et al., 2001). Furthermore, the lawn established for sports activities is at the same time an agronomic cultivation which confers green surface for photosynthetic activity and represents an ecological culture able to reduce the carbon dioxide content in the atmosphere (Watschke and Schmidt, 1992). An artificial soil profile, such as sandy soil, peat and organic components, used for implanting turves, interferes with the physical properties of soil and physiological activities of plants, influencing nutrient uptake, growth of stems and quality of the turfgrass characteristics (Ledeboer and Skogely, 1973; Wehner et al., 1988; McCoy, 1998).

The use of artificial substrate made by organic amendments, in environments with a Mediterranean climate, may provide feeble beneficial improvements because, over time, the decomposition of organic compounds causes a negative change in the physical characteristics of the root zones and reduction of water movement in the soil profile (Ferguson et al.,

*Corresponding author: pasquale.martiniello@entecra.it
1986; Ferguson and Pepper, 1987; Waddington et al., 1992; Huang and Petrovic, 1995; Petrovic et al., 1997; McCoy, 1998; McCoy and Stehouwer, 1998).

The stress imposed by usage of green turf affects the compaction of the soil profile, causing damage of the physiological activity of the root systems and plant morphological structures such as leaf abrasion, and scuffing and tearing of tissues, with a consequent reduction of the ecological function of the lawn's green surface (Waddington et al., 1974; Canaway, 1976; Carrow and Petrovic, 1992; Trenholm et al., 1999; Li et al., 2000).

Particularly in a Mediterranean climate, nitrogen fertilization influences the development of turfgrass and its effect depends on the weather conditions during the seasons. A greater effect of fertilizer application on turf occurs from September to June. In fact, in this period the weather conditions are more favorable to the development of cool-season turf than summer months, whose strong meteorological events and long periods of the day exposed to temperatures over $33{ }^{\circ} \mathrm{C}$ reduce the physiological activity and the qualitative traits of turfgrass (Ledeboer and Skogely, 1973; McCoy and Stehouwer, 1998; Martiniello, 2001).

Turf blend binary mixture, in comparison with single cultivar turf, represents the seed source best adapted for implanting turf green structures (Watschke and Schmidt, 1992; Oral and Açýkgöz, 2001). Lawns made using blends are less susceptible to variations in meteorological conditions than those made with one cultivar and able to compensate for the negative 


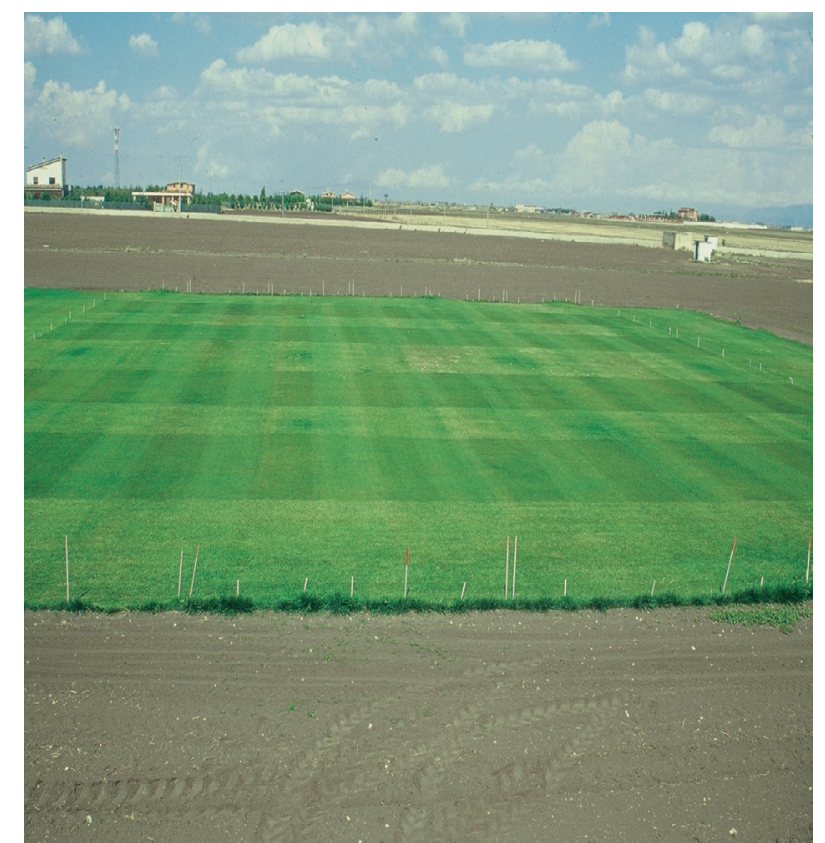

Figure 1. Panoramic view of the green turf experiment developed on four substrates and made by three binary mixture blends under two levels of nitrogen and traffic stress treatments in an environment with a Mediterranean climate.

effect of weather conditions occurring during the period of turf growing (Beard, 1973; Vengris and Torello, 1982; Watschke and Schmidt, 1992; Oral and Açýkgöz, 2001). Thus, efficient cultivation techniques utilized for establishing and management of turfgrass sport fields represent a sustainable agronomic activity for reducing the impact factors for maintaining green surface and increasing the ecological purpose of physiological processes able to reduce pollution of the atmosphere (Watschke and Schmidt, 1992) (Fig. 1).

The objective of the experiment was to investigate the effect of traffic stress on relationships among soil profile substrates, binary mixture blends, nitrogen fertilization and qualitative characteristics of traits in turf lawns to establish sustainable and efficient agronomic turfgrass sport fields and simultaneously provide an ecological green structure which reduces the impact of atmospheric pollution in a Mediterranean climate.

\section{MATERIALS AND METHODS}

The experiment was established in October of 1998, at the Menichella farm at the CRA Forage Crop Institute, in Foggia, in Southern Italy. The farm is located at $15^{\circ} 33^{\prime} \mathrm{E}, 41^{\circ} 18^{\prime} \mathrm{N}$, at an elevation of $76 \mathrm{~m}$ above sea level. Annual means, over the last 15 years, were $15.9^{\circ} \mathrm{C}$ for temperature, $399 \mathrm{~mm}$ for rainfall and $1686 \mathrm{~mm}$ for evaporated water from a Class A water pan. Rainfall in late spring and summer is limited and erratic in this environment. $80 \%$ of precipitation falls during the period October to June, and in the same period the water evaporation was $41 \%$ of the total amount (Martiniello, 2001).
Four substrates, with different soil composition, were studied to evaluate the effect of traffic stress impact and nitrogen fertilization on 3 turfgrass binary seed variety blend mixtures. Each substratum was $9 \mathrm{~m}$ wide and $36 \mathrm{~m}$ long with a total surface of $324 \mathrm{~m}^{2}$. The substrates were contiguously located and separated by a turfgrass alley of $1 \mathrm{~m}$. The depth of all substrates was $70 \mathrm{~cm}$. To facilitate drainage, a $7-\mathrm{cm}$-deep layer of coarse stone, $2-3 \mathrm{~mm}$ in diameter, was applied at the bottom of the substrate.

Irrigation of the experimental field was done by an underground irrigated system endowed with automatic rotary sprinkler equipment. Water application was carried out when the moisture content of the topsoil reached a value of $\mathrm{pF} 4.0,85$ $90 \%$ of the water-holding capacity.

The four root zones of the substrate profile were named: substrate 1, 80:20, sand:peat $\mathrm{v} / \mathrm{v}$, built utilizing the sand patented by the United States Golf Association; substrate 2, 85:10:5, sand:silt-clay:peat v/v; substrate 3, 67:30:3, sand:siltclay-peat $\mathrm{v} / \mathrm{v}$, amended by mixing $50 \%$ of natural sand and as much autochthonous soil volume; and substrate 4, 35:60:5, sand:silt-clay:peat $\mathrm{v} / \mathrm{v}$, derived from local autochthonous soil. The particle size pattern of the soil components used in the root-zone profile are presented in Table I.

Simulated traffic stress was applied on the green surface of the four substrates by a mechanical device using studded rotors, $100 \mathrm{~cm}$ in diameter, mounted on two axles. The front and back axle rotors are parallel in order to both cover and overpass on the same surface and run at the same speeds to provide an equal-slip action on the turfgrass green. Studs are welded on the front surface of the two rollers, as they are on football boots. The device was moved by a small tractor, lower than 20 Horse Power, with a low tyre pressure. The different traffic stress levels were imposed by varying the number of the forward and reverse passes on the green surface. The intensity of traffic stress was recorded according to the number of forward and reverse passes. The effect of the traffic stress was compared with the control treatment, where no traffic stress was applied. The soil moisture conditions of the substrate during stress application were $85-89 \%$ of the water-holding capacity. The simulated traffic stress imposed on the treatments of the experiment were: control with no stress applied, and the first and second levels of traffic stress were carried out, respectively, by 10 and 20 passes of the mechanical device per week over a year on the green surface of the plot.

Nitrogen fertilizer was applied in all treatments at two experimental levels: low and high levels, respectively, at 100 and $200 \mathrm{~N}$ units ha $\mathrm{yr}^{-1} \mathrm{yr}^{-1}$. The fertilizer was manually applied in each plot four times, in October, January, April and June, at the rates of 25 and $50 \mathrm{~kg} \mathrm{ha}^{-1}$ for the low and high level, respectively. Nitrogen fertilizer treatment, in all years of evaluation and at each time of application, was always applied as ammonium nitrate at the rate of 0.26 units per $\mathrm{kg}$.

Three varieties binary mixture blends were tested in the study. The species and the variety used for preparing the seed source were: Lolium perenne L. "cv Brightstar", Festuca arundinacea Schreb. "cv Safary", Poa pratensis L. "cv Midnight" and Cynodon dactylon (L.) Pers. "cv Jackpot". The amount of seed weight of the binary mixture was prepared by blending 
Table I. Particle size analysis of media used in the four sustrates.

\begin{tabular}{ccccccc}
\hline & & Very & \multicolumn{5}{c}{ Sand } & Silt \& \\
\cline { 4 - 6 } Type of soil & Gravel & coarse & coarse & fine & very fine & clay \\
profile & $>2.0$ & $2.0-1.0$ & $1.0-0.5$ & $0.25-0.01$ & $0.01-0.05$ & $<0.05$ \\
\hline & \multicolumn{7}{c}{$\varnothing \begin{array}{c}0 \text { mm } \\
\text { Substrate } 1 *\end{array}$} & 3 & 10 & 58 & 16 & 5 & 8 \\
Substrate 2 & 2 & 2 & 9 & 70 & 16 & 1 \\
Substrate 3 & 1 & 6 & 8 & 35 & 25 & 25 \\
Substrate 4 & 1 & 8 & 10 & 11 & 25 & 45 \\
\hline
\end{tabular}

* Percentage of each diameter size retained on each sieve (by weight).

the seeds of the species components in the following seed weight ratio: binary mixture $1=L$. perenne, $26 \mathrm{~g} \mathrm{~m}^{-2}+$ $P$. pratensis, $9 \mathrm{~g} \mathrm{~m}^{-2}$; binary mixture $2=F$. arundinacea, $26 \mathrm{~g} \mathrm{~m}^{-2}+P$. pratensis, $9 \mathrm{~g} \mathrm{~m}^{-2}$; and binary mixture $3=L$. perenne, $26 \mathrm{~g} \mathrm{~m}^{-2}+C$. dactylon, $4 \mathrm{~g} \mathrm{~m}^{-2}$.

Plot surface was $6 \mathrm{~m}^{2}, 2 \mathrm{~m} \times 3 \mathrm{~m}$. The binary mixture blends were sown by hand. Before seeding, $4 \mathrm{~g} \mathrm{~m}^{-2}$ of $\mathrm{P}_{2} \mathrm{O}_{5}$ fertilizer, as superphosphate, was supplied. In the following year of evaluation, the same amount of $\mathrm{P}_{2} \mathrm{O}_{5}$ was applied in the winter period before turfgreen aeration practices. When needed, the plots were hand-weeded. The plots were clipped when the turfgrass was $50 \mathrm{~mm}$ tall, mowed at a height of $35 \mathrm{~mm}$, recovering and discarding the clippings.

In February, the plots were aerated using a hollow-core with 16-mm tines at $60-\mathrm{mm}$ spacing. The traits considered in the study were: turf quality, evaluated establishment, density, texture and uniformity of the green; turf color and turf cover assessed, respectively, the ability of plants to hold color and uniformity of stems and uniformity of the surface covered by shoots in the lawn. All traits were evaluated monthly from January to December, adopting similar assessments used by the National Turfgrass Evaluation Program in the USA. The traits were determined using a visual score based on a 9-level scale; where for turf quality, color and cover traits, $1=$ very poor quality of turf, brown color and bare soil cover while $9=$ outstanding ideal turf, dark green color and very dense cover.

The putting greens of 4 different soil profiles were considered strip treatments in the experimental design. The effect of the substrate was assessed by a stratified simple random sampling model experimental design (Steel and Torrie, 1980). Each year of evaluation was considered a replication of the substrate. Within the substrate treatment, factors were assessed by a randomized block design model. In particular, experimental entries were analyzed with a split-split-plot in time model with randomized blocks with three replications. In the model the main plot was fertilization with 2 levels; sub-plot traffic stress with 3 levels; and sub-sub-plot binary mixture blends with 3 levels (Steel and Torrie, 1980). The total number of plots considered in each substrate experiment was 54. The ANOVA used for evaluating substrate treatments was a mixed model with years and replication random effects and fertilizations, traffic stresses and mixture blends as fixed effects. Also, interactions among treatments were tested and when a significant ( $\alpha=0.05)$ F-ratio occurred in the two- or three-factor
Table II. Mean squares among treatments (substrates and years) evaluated over a five years period.

\begin{tabular}{lcccc}
\hline & & \multicolumn{3}{c}{ Mean squares } \\
\cline { 3 - 5 } Source & df & quality & color & cover \\
\cline { 3 - 5 } of variation & 4 & $44.3^{* *}$ & $118.0^{* *}$ & $118.0^{* *}$ \\
\hline Years (Y) & 3 & $126.0^{* *}$ & $94.1^{* *}$ & $94.1^{* *}$ \\
Substrates (S) & 3 & 7.4 & 9.8 & 10.1 \\
Error & 12 & &
\end{tabular}

*** Significant at the 0.05 and 0.01 probability levels.

interactions a least significant difference, LSD, at a $P=0.05$ probability level was calculated.

\section{RESULTS AND DISCUSSION}

\subsection{Turfgrass quality}

Year mean squares variability was $64.8 \%$ lower in turf quality and $20.3 \%$ higher in both turf color and cover traits than those of substrates (Tab. II). The greater year mean squares values of all qualitative traits than substrates was a consequence of the yearly weather conditions effect on turfgrass lawns by blend binary mixture, fertilizer and traffic stress treatments (Tab. III). Across the year of evaluation, the mean squares of the qualitative traits within substrates were higher in the factors fertilizers and blend binary mixtures than the values of the traffic stress treatment. In agreement with Joo et al. (2001), the greater amount of the mean square variability among substrates was a consequence of soil profile composition. Root zones with higher sand content of substrate 1 and substrate 2, as an effect of lower soil water retention, in all qualitative traits showed greater mean squares in blend binary mixture and fertilizer treatments than the sand-amended profile of substrate 3 and autochthonous soil of substrate 4 (Tab. III). The statistical significance of mean squares of interactions: two-factor, year $\times$ blend binary mixture and year $\times$ nitrogen fertilizer and three-factor, blend binary mixture $\times$ nitrogen fertilizer $\times$ traffic stress, was ascribed to different effects of the year's weather conditions on the binary mixture, nitrogen fertilizer and traffic stress effects on the qualitative turfgrass characteristics of the substrates (Tab. III). Furthermore, because in all substrates, the turf color was statistically significant in the two-factor interaction: nitrogen $\times$ traffic stress, this 
Table III. Mean squares within substrates under fertilizers, binary blend mixtures and traffic stress treatments evaluated in five years of evaluation in environment with Mediterranean climate.

\begin{tabular}{|c|c|c|c|c|c|c|c|c|c|c|c|c|c|}
\hline \multirow{3}{*}{ Source } & & \multicolumn{12}{|c|}{ Mean squares } \\
\hline & & \multicolumn{3}{|c|}{ Turf } & \multicolumn{3}{|c|}{ Turf } & \multicolumn{3}{|c|}{ Turf } & \multicolumn{3}{|c|}{ Turf } \\
\hline & & \multicolumn{3}{|c|}{ Substrate 1} & \multicolumn{3}{|c|}{ Substrate 2} & \multicolumn{3}{|c|}{ Substrate 3} & \multicolumn{3}{|c|}{ Substrate 4} \\
\hline Blend $(\mathrm{M})$ & 2 & $20.3 * *$ & $9.1 * *$ & $5.8 * *$ & $0.78 * *$ & $0.64 * *$ & $0.54 *$ & $6.4 * *$ & $4.9 * *$ & $2.5 * *$ & $10.7 * *$ & $0.12 * *$ & $6.7 * *$ \\
\hline Fertilizer $(\mathrm{N})$ & 1 & $16.7 * *$ & $25.1 * *$ & $8.4 * *$ & $8.5^{* *}$ & $12.4 * *$ & $11.6^{* *}$ & $10.8 * *$ & $25.0 * *$ & $11.0 * *$ & $4.4 * *$ & $9.1 * *$ & $10.4 * *$ \\
\hline Traffic stress $(\mathrm{T})$ & 2 & $0.75^{*}$ & $0.51 *$ & $1.8^{*}$ & $0.22 *$ & $0.42 *$ & $0.66^{*}$ & $0.38^{*}$ & $0.88 *$ & $0.61 *$ & $0.48 *$ & $0.31 *$ & $0.54 *$ \\
\hline $\mathrm{Y} \times \mathrm{N}$ & 4 & $2.8 * *$ & $1.9 * *$ & $2.7 * *$ & $1.4 * *$ & $2.1 *$ & $1.9 * *$ & $1.5^{*}$ & $2.9 * *$ & $3.1 * *$ & $1.1 * *$ & $2.4 * *$ & $1.9 * *$ \\
\hline $\mathrm{Y} \times \mathrm{T}$ & 8 & $0.01 \mathrm{~ns}$ & $0.05 \mathrm{~ns}$ & $0.22 \mathrm{~ns}$ & $0.03 \mathrm{~ns}$ & $0.03 \mathrm{~ns}$ & $0.05 \mathrm{~ns}$ & $0.02 \mathrm{~ns}$ & $0.08 \mathrm{~ns}$ & $0.09 \mathrm{~ns}$ & $0.05 \mathrm{~ns}$ & $0.01 \mathrm{~ns}$ & $0.1 \mathrm{~ns}$ \\
\hline $\mathrm{M} \times \mathrm{N}$ & 2 & $0.6 \mathrm{~ns}$ & $0.1 \mathrm{~ns}$ & $0.21 \mathrm{~ns}$ & $0.17 \mathrm{~ns}$ & $0.21 \mathrm{~ns}$ & $0.65 \mathrm{~ns}$ & $0.35^{*}$ & $0.81 * *$ & $0.14 \mathrm{~ns}$ & $0.03 \mathrm{~ns}$ & $0.03 \mathrm{~ns}$ & $0.38 \mathrm{~ns}$ \\
\hline $\mathrm{M} \times \mathrm{T}$ & 4 & $0.04 \mathrm{~ns}$ & $0.07 \mathrm{~ns}$ & $0.12 \mathrm{~ns}$ & $0.51 \mathrm{~ns}$ & $0.01 \mathrm{~ns}$ & $0.13 \mathrm{~ns}$ & $0.04 \mathrm{~ns}$ & $0.09 \mathrm{~ns}$ & $0.06 \mathrm{~ns}$ & $0.04 \mathrm{~ns}$ & $0.09 \mathrm{~ns}$ & $0.07 \mathrm{~ns}$ \\
\hline $\mathrm{N} \times \mathrm{T}$ & 2 & $0.24 \mathrm{~ns}$ & $0.64 *$ & $0.90 *$ & $0.14 \mathrm{~ns}$ & $0.30 *$ & $0.38 \mathrm{~ns}$ & $0.19 *$ & $0.31 *$ & $0.15 \mathrm{~ns}$ & $0.06 \mathrm{~ns}$ & $0.35^{*}$ & $0.05 \mathrm{~ns}$ \\
\hline
\end{tabular}

*** Significant at the 0.05 and 0.01 probability levels, respectively. ns = not significant.

Table IV. Main effect of substrates on turfgrass traits evaluated in five years of experiments.

\begin{tabular}{lccc}
\hline Media profile & \multicolumn{3}{c}{ Turf } \\
\cline { 2 - 4 } & quality & color & cover \\
\hline Substrate 1 & 6.3 & 6.3 & 6.3 \\
Substrate 2 & 7.1 & 6.9 & 6.9 \\
Substrate 3 & 7.3 & 7.1 & 7.4 \\
Substrate 4 & 7.8 & 7.3 & 7.3 \\
Mean & 7.0 & 6,8 & 6,8 \\
LSD $_{0.05}$ & 0.2 & 0.2 & 0.2 \\
\hline
\end{tabular}

evidenced a higher influence of the fertilizers and condition of traffic on the color rather than quality and cover characteristics of the turfgrass (Tab. III).

\subsection{Substrate 1}

The main particles present in the soil profile of the media were composed by $89 \%$ sand and $8 \%$ silt clay, which conferred upon the media a poor physical property to retain water during plant turf growing (Tab. I). The $200 \mathrm{~N}$ units of fertilization under control without traffic stress treatment was statistically not significant compared with the $100 \mathrm{~N}$ units fertilization (Fig. 2a). The mean values among turf quality, color and cover traits recorded on the substrate were similar and lower by $14.9 \%, 11.3 \%$ and $13.7 \%$ than the means of the other substrates (Tab. IV). Under fertilizer treatment of $100 \mathrm{~N}$ units with blend binary mixture 2 of the control with no traffic stress treatment, turf quality, color and cover traits were higher by, respectively, $11.5 \%, 9.9 \%$ and $6.0 \%$ than the means of binary mixture 1 and binary mixture 3 (Tab. V). The mean score of blend binary mixtures and fertilizer treatments at the second level of traffic stress reduced the values of the traffic control
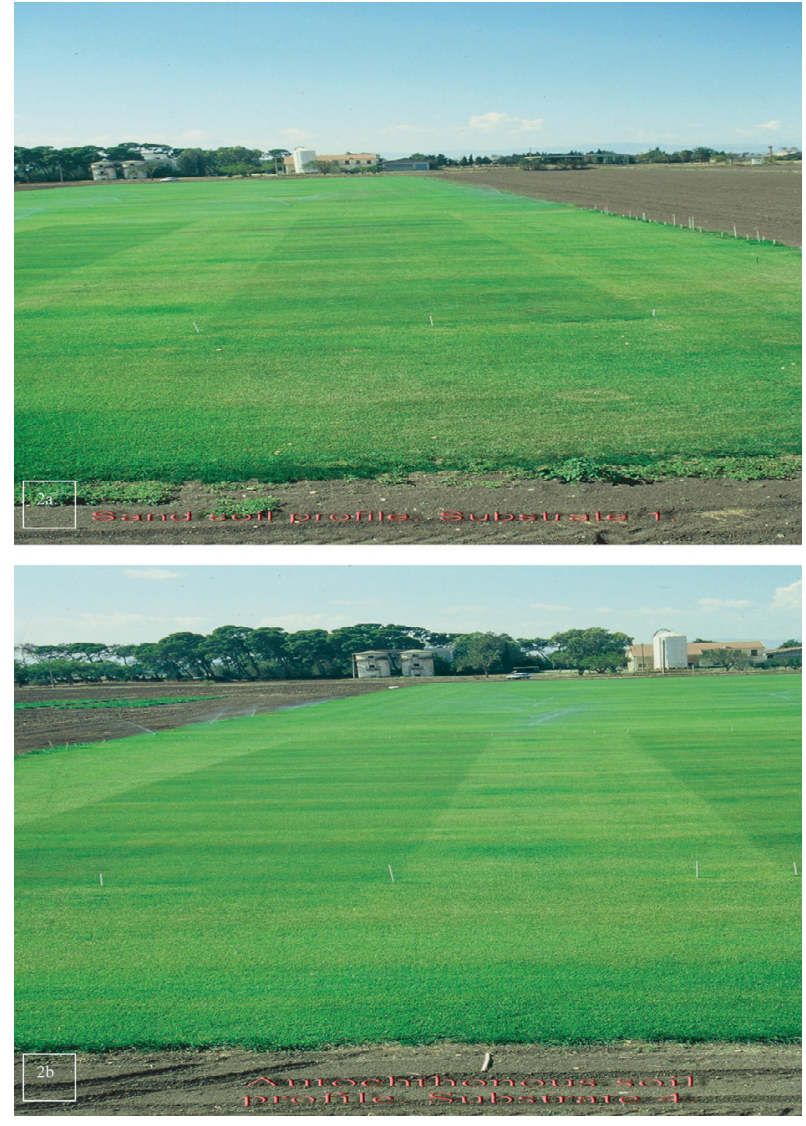

Figure 2. Visual evaluation of green turfgrass binary mixture blends developed on sand soil (2a) vs. autochthonous (2b) profiles under two levels of nitrogen and traffic stress treatments in an environment with a Mediterranean climate. The treatments included in the experiment are delimited by grey stakes. Watering the green field is not include in the experiment. 
Table V. Mean over a period of five years of the evaluation. Effect of fertilization and traffic stress treatments on blend mixtures growth on soil substrate 1 .

\begin{tabular}{|c|c|c|c|c|c|c|c|c|c|c|c|c|}
\hline \multirow{4}{*}{ Treatment } & \multicolumn{12}{|c|}{ Soil profile with media USGA } \\
\hline & \multicolumn{3}{|c|}{ Turf quality } & \multirow{3}{*}{$\mathrm{LSD}_{0.05}$} & \multicolumn{4}{|c|}{ Turf color } & \multicolumn{3}{|c|}{ Turf cover } & \multirow{3}{*}{$\mathrm{LSD}_{0.05}$} \\
\hline & \multicolumn{3}{|c|}{ Blend mixture } & & \multicolumn{3}{|c|}{ Blend mixture } & \multirow[t]{2}{*}{$\overline{\mathrm{LSD}_{0.05}}$} & \multicolumn{3}{|c|}{ Blend mixture } & \\
\hline & BM 1 & BM 2 & BM 3 & & BM 1 & BM 2 & BM 3 & & BM 1 & BM 2 & BM 3 & \\
\hline N $100 \mathrm{~kg} \mathrm{ha}^{-1} \mathrm{yr}^{-1}$ & & & & & & & & & & & & \\
\hline Traffic stress: & & & & & & & & & & & & \\
\hline STS 1 & 6.6 & 7.0 & 5.9 & 0.3 & 6.0 & 6.9 & 6.1 & 0.3 & 6.3 & 6.7 & 6.0 & 0.2 \\
\hline STS 2 & 5.9 & 6.4 & 5.7 & 0.2 & 5.7 & 6.3 & 5.4 & 0.2 & 5.8 & 6.0 & 5.5 & 0.2 \\
\hline STS 3 & 5.5 & 6.1 & 5.3 & 0.2 & 5.1 & 6.1 & 5.2 & 0.3 & 5.4 & 5.8 & 5.1 & 0.2 \\
\hline Mean & 6.0 & 6.5 & 5.7 & & 5.6 & 6.4 & 5.6 & & 5.8 & 6.2 & 5.5 & 0.3 \\
\hline $\mathrm{LSD}_{0.05}$ & 0.3 & 0.3 & 0.2 & & 0.3 & 0.2 & 0.3 & & 0.2 & 0.3 & 0.3 & \\
\hline N $200 \mathrm{~kg} \mathrm{ha}^{-1} \mathrm{yr}^{-1}$ & & & & & & & & & & & & \\
\hline Traffic stress: & & & & & & & & & & & & \\
\hline STS 1 & 6.0 & 6.9 & 6.1 & 0.3 & 6.2 & 6.8 & 6.4 & 0.2 & 6.5 & 6.6 & 6.2 & 0.1 \\
\hline STS 2 & 5.6 & 6.7 & 5.8 & 0.3 & 5.8 & 6.4 & 5.9 & 0.2 & 5.6 & 5.9 & 5.9 & 0.1 \\
\hline STS 3 & 5.1 & 6.4 & 5.3 & 0.4 & 5.3 & 6.0 & 5.7 & 0.2 & 5.2 & 5.6 & 5.3 & 0.1 \\
\hline Mean & 5.6 & 6.7 & 5.7 & & 5.7 & 6.4 & 6.0 & & 5.8 & 6.0 & 5.8 & \\
\hline $\mathrm{LSD}_{0.05}$ & 0.3 & 0.2 & 0.2 & & 0.3 & 0.2 & 0.2 & & 0.4 & 0.3 & 0.3 & \\
\hline Mean & 5.8 & 6.6 & 5.7 & 0.5 & 5.7 & 6.4 & 5.8 & & 5.8 & 6.1 & 5.7 & \\
\hline $\mathrm{LSD}_{0.05}$ & 0.1 & 0.1 & NS & & 0.04 & NS & 0.10 & & NS & 0.03 & 0.06 & \\
\hline
\end{tabular}

by $13.3 \%$ in all turf qualitative traits and those of the first level of traffic stress by $6.7 \%, 5.1 \%$ and $6.7 \%$; respectively, turf quality, color and cover traits. The reduction of the turfgrass qualitative characteristics of the control without traffic stress, under both fertilizer and blend binary mixture treatments, at the first and second levels of traffic stress treatments was, respectively, $6.8 \%$ and $12.5 \%$ for turf quality, $7.8 \%$ and $12.5 \%$ for turf color and $9.4 \%$ and $15.6 \%$ for turf cover. According to O'Neil and Carrow (1983) and Shearman et al. (2001), the lack of score values due to traffic stress was a consequence of soil compaction, which destroys the macroaggregate, reducing the capacity of roots to grow and injuring the uptake activity of the sap from the soil, promoting a chronic effect on turf quality characteristics of shoots.

The mean scores over both nitrogen fertilizer and traffic stress treatments of turfgrass of the blend binary mixture 2, because tall fescue was a main component in the seed source, was higher by $12.5 \%$ in turf quality, $11.7 \%$ in turf color and $13.9 \%$ in turf cover than the means of the other blend binary mixtures. It represents the ecological turfgrass seed source best able to make lawns develop under the soil properties of the substrate (Turgeon, 1999; Voigt et al., 2001).

\subsection{Substrate 2}

The soil particles of the substrate were represented by $70 \%$ of fine sand and $16 \%$ of very fine particles, with other soil components in lower amounts (Tab. I). The $200 \mathrm{~N}$ units increased the mean values, over blend binary mixture and levels of traffic stress, of the $100 \mathrm{~N}$ units treatment by $7.2 \%$ in turf quality, $6.1 \%$ in turf color and $4.1 \%$ in turf cover. According to Huang and Fu (2001) and Miltner et al. (2001), the improvement in lawn quality observed under $200 \mathrm{~N}$ units was a consequence of the availability of the nitrogen in the soil profile. The lower values of turf color under $100 \mathrm{~N}$ than $200 \mathrm{~N}$ units were due, as reported by Wilkinson and Duff (1972) and Miltner et al. (1996), to utilization of the applied nitrogen which, when available at low concentration in the root zones, favored mainly turf growing rather than leaf color.

The mean score values of blend binary mixture 2 , over the mean of traffic stress levels under $200 \mathrm{~N}$ units, were $7.1 \%$, $5.9 \%$ and $5.3 \%$ higher than the value recorded under $100 \mathrm{~N}$ units, respectively, in turf quality, color and cover traits. The greater adaptability of blend binary mixture 2 was also observed under $100 \mathrm{~N}$ units treatment. The mean scores of the blend mixture 2 over the level of traffic stress was higher than blend mixture 1 and blend mixture 3; respectively, $3.1 \%$ and $1.5 \%$ in turf quality; $1.6 \%$ and $9.8 \%$ in turf color traits. The turf cover traits showed small differences among blend mixtures at both levels of nitrogen units (Tab. VI). In agreement with Haung and Fu (2001), Oral and Açýkgöz (2001), Voigt et al. (2001) and Russi et al. (2004), the better adaptation of the blend binary mixture 2 was attributed to the tall fescue component, which confers upon the green surface of turfgrass more tolerance to weather than the species present in the other blends.

The effect of the second level of traffic stress, mean over blend mixtures, reduced by $10.3 \%$ and $3.2 \%$ under $100 \mathrm{~N}$ units and $8.3 \%$ and $4.3 \%$ under $200 \mathrm{~N}$ units the score value of turf quality, respectively, in the control and first level of traffic stress. A similar trend of reduction was observed in turf color and cover traits (Tab. VI). Furthermore, the first level of traffic stress under $100 \mathrm{~N}$ units mean, over blend binary mixtures score, was $3.2 \%$ lower for turf quality and color and $4.2 \%$ lower for cover traits than the second level of traffic stress. 
Table VI. Mean over a period of five years of the valuation. Effect of fertilization and traffic stress treatments on blend mixtures razed on substrate 2 .

\begin{tabular}{|c|c|c|c|c|c|c|c|c|c|c|c|c|}
\hline \multirow{4}{*}{ Treatment } & \multicolumn{12}{|c|}{ Soil profile with sand media } \\
\hline & \multicolumn{3}{|c|}{ Turf quality } & & \multicolumn{4}{|c|}{ Turf color } & \multicolumn{3}{|c|}{ Turf cover } & \multirow{3}{*}{$\mathrm{LSD}_{0.05}$} \\
\hline & \multicolumn{3}{|c|}{ Blend mixture } & \multirow{2}{*}{$\overline{\mathrm{LSD}_{0.05}}$} & \multicolumn{3}{|c|}{ Blend mixture } & \multirow[t]{2}{*}{$\operatorname{LSD}_{0.05}$} & \multicolumn{3}{|c|}{ Blend mixture } & \\
\hline & BM 1 & BM 2 & BM 3 & & BM 1 & BM 2 & BM 3 & & $\overline{\mathrm{BM} 1}$ & $\overline{\mathrm{BM}} 2$ & BM 3 & \\
\hline N $100 \mathrm{~kg} \mathrm{ha}^{-1} \mathrm{yr}^{-1}$ & & & & & & & & & & & & \\
\hline Traffic stress: & & & & & & & & & & & & \\
\hline STS 1 & 6.7 & 6.9 & 6.8 & 0.0 & 6.5 & 6.7 & 6.4 & 0.1 & 7.3 & 7.5 & 7.3 & 0.0 \\
\hline STS 2 & 6.2 & 6.5 & 6.3 & 0.1 & 6.3 & 6.3 & 6.0 & 0.1 & 7.1 & 7.1 & 7.1 & 0.0 \\
\hline STS 3 & 5.9 & 6.2 & 6.1 & 0.1 & 6.1 & 6.1 & 5.7 & 0.1 & 6.8 & 6.7 & 7.0 & 0.1 \\
\hline Mean & 6.3 & 6.5 & 6.4 & & 6.3 & 6.4 & 6.0 & & 7.1 & 7.1 & 7.2 & \\
\hline LSD 0.05 & 0.2 & 0.2 & 0.2 & & 0.1 & 0.2 & 0.2 & & 0.1 & 0.2 & 0.1 & \\
\hline $\mathrm{N} 200 \mathrm{~kg} \mathrm{ha}^{-1} \mathrm{yr}^{-1}$ & & & & & & & & & & & & \\
\hline Traffic stress: & & & & & & & & & & & & \\
\hline STS 1 & 7.2 & 7.3 & 7.0 & 0.1 & 7.0 & 7.1 & 6.9 & 0.0 & 7.5 & 7.9 & 7.7 & 0.1 \\
\hline STS 2 & 6.9 & 7.0 & 6.8 & 0.1 & 6.6 & 6.8 & 5.5 & 0.4 & 7.3 & 7.5 & 7.4 & 0.0 \\
\hline STS 3 & 6.6 & 6.8 & 6.4 & 0.1 & 6.2 & 6.6 & 6.2 & 0.1 & 7.1 & 7.2 & 7.1 & 0.0 \\
\hline Mean & 6.9 & 7.0 & 6.8 & & 6.6 & 6.8 & 6.2 & & 7.3 & 7.5 & 7.4 & \\
\hline LSD 0.05 & 0.2 & 0.1 & 0.2 & & 0.2 & 0.1 & 0.4 & & 0.1 & 0.2 & 0.2 & \\
\hline Mean & 6.6 & 6.8 & 6.6 & & 6.4 & 6.6 & 6.1 & & 7.2 & 7.3 & 7.3 & \\
\hline LSD 0.05 & 0.14 & 0.12 & 0.09 & & 0.06 & 0.10 & 0.04 & & 0.05 & 0.09 & 0.06 & \\
\hline
\end{tabular}

The mean reduction of blend binary mixtures score, observed in the first over the second level of traffic stress, was $3.2 \%$ for turf quality and color and $4.2 \%$ in cover traits under $100 \mathrm{~N}$ units and over $4.2 \%$ in all turf traits under $200 \mathrm{~N}$ units treatment. Thus, the effect of $200 \mathrm{~N}$ units treatment increased the damage caused by the first level of traffic stress on the qualitative characteristics of the lawn (Tab. VI). However, considering the effect of nitrogen fertilization and traffic stress treatments on blend binary mixtures, it is worth noting that the binary mixture 2 and $100 \mathrm{~N}$ units were the agronomic factors best able to exploit and ecologically sustain the qualities of turf green.

\subsection{Substrate 3}

The profile of the substrate was composed of three main components, fine and very fine sand, silt and clay, whose amount represents $85 \%$ of the total particles (Tab. I).

The means of blend binary mixtures over $200 \mathrm{~N}$ units treatment of the traffic stress control increased the mean score of $100 \mathrm{~N}$ units by $5.6 \%, 9.2 \%$ and $6.8 \%$, respectively, for turf quality, color and cover traits (Tab. VII). However, the adaptability of blend mixtures under the $200 \mathrm{~N}$ units of the traffic stress control depended on the trait: blend mixture 2 was $7.8 \%$ higher in turf quality, blend mixture 3 was $3.1 \%$ higher in turf color; and blend mixture 1 was $4.0 \%$ higher in the turf cover traits than the means of other blends (Tab. VII). Thus, the $200 \mathrm{~N}$ units favor the exploitation of the environmental condition of the turf color and cover traits, respectively, in blend mixture 3 and blend mixture 1, composed of the species less tolerant to weather conditions such as perennial ryegrass and Kentucky bluegrass, than the tall fescue of the blend mixture 2
(Tab. VII). By contrast, the mean values of the binary mixture 2 over traffic stress treatment, under $100 \mathrm{~N}$ units, showed $4.5 \%$ and $6.1 \%$ greater scores than the means of blend mixture 1 and blend mixture 3 . The greater adaptability of the blend binary mixture 2 was due to the tall fescue component, which conferred upon the turf lawns the physiological peculiarities, as postulated by Turgeon (1999) and Voigt et al. (2001), to withstand a wide range of environmental conditions and to the external stress management imposed by traffic treatment and soil fertility on the root-zone profile.

The mean of traffic stress over the mean of blend mixtures interfered with the levels of nitrogen-fertilized treatment, reducing the score values of the control with no traffic stress, of turf quality, color and cover traits under $100 \mathrm{~N}$ units, respectively, by $4.4 \%, 2.3 \%$ and $1.5 \%$ at the first level and $10.1 \%$, $3.4 \%$ and $4.3 \%$ at the second level of traffic stress. A comparable trend of reduction achieved under $100 \mathrm{~N}$ units was observed in the traffic stress control vs. levels of traffic stress in all qualitative traits under $200 \mathrm{~N}$ units (Tab. VII). However, the mean of the second level of traffic stress over blend mixtures reduced under $100 \mathrm{~N}$ units the score values of the first level of traffic stress in turf quality, color and cover traits, respectively, by $6.1 \%, 1.7 \%$ and $2.9 \%$; a similar trend of reduction was observed among turf quality traits under the $200 \mathrm{~N}$ units fertilization. Anyhow, both $100 \mathrm{~N}$ and $200 \mathrm{~N}$ units favor exploitation of the green turf of blend mixture 2 rather than blend mixture 1 . The effect of $200 \mathrm{~N}$ units treatment increased the mean of traffic stress score values recorded in the $100 \mathrm{~N}$ units treatment by $5.9 \%$ in turf quality, $5.7 \%$ in turf color and $2.9 \%$ in turf cover traits. According to Miltner et al. (2001), the improvement in lawn quality promoted by $200 \mathrm{~N}$ in comparison with $100 \mathrm{~N}$ units was a consequence of the availability of nitrogen in the root zone of the soil profile of plant development, 
Table VII. Mean over a period of five years of the valuation. Effect of fertilization and traffic stress treatments on blend mixtures razed on substrate 3 .

\begin{tabular}{|c|c|c|c|c|c|c|c|c|c|c|c|c|}
\hline \multirow{4}{*}{ Treatment } & \multicolumn{12}{|c|}{ Soil profile with amended media } \\
\hline & \multicolumn{4}{|c|}{ Turf quality } & \multicolumn{4}{|c|}{ Turf color } & \multicolumn{3}{|c|}{ Turf cover } & \\
\hline & \multicolumn{3}{|c|}{ Blend mixture } & \multirow[t]{2}{*}{$\mathrm{LSD}_{0.05}$} & \multicolumn{3}{|c|}{ Blend mixture } & \multirow[t]{2}{*}{$\mathrm{LSD}_{0.05}$} & \multicolumn{3}{|c|}{ Blend mixture } & \multirow{2}{*}{$\mathrm{LSD}_{0.05}$} \\
\hline & BM 1 & BM 2 & BM 3 & & BM 1 & BM 2 & BM 3 & & BM 1 & BM 2 & BM 3 & \\
\hline \multicolumn{13}{|l|}{$\mathrm{N} 100 \mathrm{~kg} \mathrm{ha}^{-1} \mathrm{yr}^{-1}$} \\
\hline Traffic stress: & & & & & & & & & & & & \\
\hline STS 1 & 6.8 & 7.1 & 6.8 & 0.1 & 5.7 & 6.3 & 5.8 & 0.2 & 7.0 & 7.0 & 6.8 & 0.1 \\
\hline STS 2 & 6.4 & 6.9 & 6.6 & 0.1 & 5.6 & 6.2 & 5.6 & 0.2 & 6.9 & 6.9 & 6.6 & 0.1 \\
\hline STS 3 & 6.1 & 6.4 & 6.2 & 0.1 & 5.5 & 6.1 & 5.5 & 0.2 & 6.5 & 6.7 & 6.5 & 0.1 \\
\hline Mean & 6.5 & 6.8 & 6.5 & & 5.6 & 6.2 & 5.6 & & 6.8 & 6.9 & 6.6 & \\
\hline LSD 0.05 & 0.2 & 0.2 & 0.2 & & 0.1 & 0.1 & 0.1 & & 0.1 & 0.1 & 0.1 & \\
\hline \multicolumn{13}{|l|}{$\mathrm{N} 200 \mathrm{~kg} \mathrm{ha}^{-1} \mathrm{yr}^{-1}$} \\
\hline \multicolumn{13}{|l|}{ Traffic stress: } \\
\hline STS 1 & 7.1 & 7.7 & 7.1 & 0.2 & 6.3 & 6.5 & 6.6 & 0.1 & 7.5 & 7.3 & 7.1 & 0.1 \\
\hline STS 2 & 6.8 & 7.3 & 6.8 & 0.2 & 6.1 & 6.2 & 6.3 & 0.0 & 7.2 & 7.1 & 6.8 & 0.1 \\
\hline STS 3 & 6.5 & 7.1 & 6.2 & 0.2 & 6.0 & 6.0 & 6.0 & 0.0 & 7.0 & 6.9 & 6.5 & 0.2 \\
\hline Mean & 6.8 & 7.4 & 6.7 & & 6.2 & 6.3 & 6.3 & & 7.2 & 7.1 & 6.8 & \\
\hline LSD 0.05 & 0.2 & 0.2 & 0.2 & & 0.1 & 0.2 & 0.2 & & 0.1 & 0.1 & 0.2 & \\
\hline Mean & 6.6 & 7.1 & 6.6 & & 5.9 & 6.2 & 5.9 & & 7.0 & 7.0 & 6.7 & \\
\hline LSD 0.05 & 0.08 & 0.12 & 0.04 & & 0.13 & 0.01 & 0.16 & & 0.10 & 0.05 & 0.05 & \\
\hline
\end{tabular}

Table VIII. Mean over a period of five years of the valuation. Effect of fertilization and trafficstress treatments on blend mixtures razed on substrate 4 .

\begin{tabular}{|c|c|c|c|c|c|c|c|c|c|c|c|c|}
\hline \multirow{4}{*}{ Treatment } & \multicolumn{12}{|c|}{ Soil profile with autochthonous media } \\
\hline & \multicolumn{3}{|c|}{ Turf quality } & \multirow{3}{*}{$\mathrm{LSD}_{0.05}$} & \multicolumn{3}{|c|}{ Turf color } & & \multicolumn{3}{|c|}{ Turf cover } & \\
\hline & \multicolumn{3}{|c|}{ Blend mixture } & & \multicolumn{3}{|c|}{ Blend mixture } & \multirow[t]{2}{*}{$\mathrm{LSD}_{0.05}$} & \multicolumn{3}{|c|}{ Blend mixture } & \multirow[t]{2}{*}{$\mathrm{LSD}_{0.05}$} \\
\hline & BM 1 & BM 2 & BM 3 & & BM 1 & BM 2 & BM 3 & & BM 1 & BM 2 & BM 3 & \\
\hline N $100 \mathrm{~kg} \mathrm{ha}^{-1} \mathrm{yr}^{-1}$ & & & & & & & & & & & & \\
\hline Traffic stress: & & & & & & & & & & & & \\
\hline STS 1 & 7.9 & 7.3 & 7.9 & 0.2 & 7.5 & 7.3 & 7.3 & 0.1 & 7.9 & 7.6 & 8.2 & 0.2 \\
\hline STS 2 & 7.6 & 7.2 & 7.6 & 0.1 & 7.3 & 7.2 & 6.9 & 0.1 & 7.6 & 7.4 & 8.1 & 0.2 \\
\hline STS 3 & 7.2 & 7.0 & 7.2 & 0.0 & 7.0 & 7.1 & 6.7 & 0.1 & 7.2 & 7.1 & 7.8 & 0.2 \\
\hline Mean & 7.6 & 7.2 & 7.6 & & 7.3 & 7.2 & 7.0 & & 7.6 & 7.4 & 8.0 & \\
\hline LSD 0.05 & 0.2 & 0.1 & 0.2 & & 0.1 & 0.1 & 0.2 & & 0.2 & 0.1 & 0.1 & \\
\hline N $200 \mathrm{~kg} \mathrm{ha}^{-1} \mathrm{yr}^{-1}$ & & & & & & & & & & & & \\
\hline Traffic stress: & & & & & & & & & & & & \\
\hline STS 1 & 8.1 & 7.6 & 8.1 & 0.2 & 7.7 & 7.5 & 7.7 & 0.1 & 8.5 & 8.0 & 8.3 & 0.1 \\
\hline STS 2 & 7.8 & 7.3 & 7.8 & 0.2 & 7.4 & 7.3 & 7.4 & 0.0 & 8.2 & 7.8 & 8.1 & 0.1 \\
\hline STS 3 & 7.1 & 7.1 & 7.5 & 0.1 & 7.1 & 7.1 & 7.0 & 0.0 & 8.0 & 7.5 & 8.0 & 0.2 \\
\hline Mean & 7.7 & 7.3 & 7.8 & & 7.4 & 7.3 & 7.4 & 0.0 & 8.3 & 7.7 & 8.2 & \\
\hline LSD 0.05 & 0.3 & 0.2 & 0.2 & & 0.2 & 0.1 & 0.2 & & 0.1 & 0.2 & 0.1 & \\
\hline Mean & 7.6 & 7.2 & 7.7 & & 7.3 & 7.2 & 7.2 & 0.1 & 7.9 & 7.6 & 8.1 & \\
\hline LSD 0.05 & 0.03 & 0.03 & 0.06 & & 0.02 & 0.03 & 0.09 & & 0.16 & 0.08 & 0.03 & \\
\hline
\end{tabular}

which mainly favors shoot color and establishment rather than shoot density.

\subsection{Substrate 4}

The root-zone profile was composed of five classes of particles, representing a silt and clay amount $17 \%$ lower than all particles of sand components (Tab. I). The composition of autochthonous soil achieved better exploitation of the agronom- ical effect of fertilized and traffic-stressed treatments on blend mixtures than other substrates (Tab. IV).

The $100 \mathrm{~N}$ units fertilizer level in comparison with $200 \mathrm{~N}$ reduced the value of qualitative traits over the mean of blend mixture of traffic stress levels by $2.6 \%, 4.1 \%$ and $3.8 \%$, respectively, in the turf quality, color and cover traits (Tab. VIII). The physical soil properties of $100 \mathrm{~N}$ and $200 \mathrm{~N}$ units treatment favored the development of the blend mixtures of binary mixture 1 and binary mixture 3 rather than blend binary 
mixture 2. The reduction of means recorded on blend mixture 2, under traffic stress control of $100 \mathrm{~N}$ units, was 7.6\% lower in turf quality, $2.7 \%$ in turf cover and $3.8 \%$ and $7.3 \%$ in cover traits than the means of blend mixture 1 and blend mixture 3. In agreement with Waddington et al. (1974), Petrovic et al. (1997), McCoy and Stehouwer (1998), and Li et al. (2000), the higher effect of $100 \mathrm{~N}$ and $200 \mathrm{~N}$ units in all turf quality traits of blend binary mixture 1 and blend mixture 3 , in comparison with those of blend mixture 2 , was a consequence of the physical soil and nutrient retention properties of the root profiles, which favor the qualitative characteristics of turf establishment (Fig. 2b). The second level of traffic stress reduced the score values over blend mixtures under $100 \mathrm{~N}$ units, respectively, under control and the first level of traffic stress by $7.8 \%$ and $5.3 \%$ in turf quality, $5.5 \%$ and $4.2 \%$ in color and $6.3 \%$ and $3.9 \%$ in cover traits. Under $200 \mathrm{~N}$ units, the effect on turf qualitative traits under the second level of traffic stress, over the control and first level of traffic stress treatment, was similar to that of $100 \mathrm{~N}$ units. The results evidenced that the physical characteristics of the substrate favor the utilization of nitrogen availability of root zones to sustain the plant physiological activity of turf qualitative traits and exploit the ecological potential of component perennial ryegrass and Kentucky bluegrass well adapted in favorable environments (Wilkinson and Duff, 1972; Miltner et al., 1996; Russi et al., 2004). However, the turfgrass qualitative traits recorded under $200 \mathrm{~N}$ units, and the use of the seed source of the blend binary mixtures 1 and 3 were the appropriate agronomic techniques of management able to exploit the potential characteristics of sustainable cultivars for establishing green turf in a Mediterranean environment.

\section{CONCLUSION}

The qualitative characteristics of turfgrass during sports activities were related to the techniques of management and to traffic stress imposed on the lawn's green surface, and represent an ecological green surface able to reduce pollution in towns. The $200 \mathrm{~N}$ units fertilizer increased all the qualitative characteristics of turf lawn. Its effects were better expressed on a soil profile with the physical characteristics of substrate 4 and substrate 3 rather than those of substrate 1 and substrate 2 . The physical soil characteristics of substrate 3 and substrate 4 reduced the damage of traffic stress and favored the ecological utilization of the blend binary mixture developed from tall fescue rather than perennial ryegrass, Kentucky bluegrass or bermudagrass. The effects of levels of traffic stress promoted reduction of the turf color and quality characteristics of lawns, whose amount of damage was related to the level of stress and to $\mathrm{N}$ fertilizer treatments. The blend binary mixture 2 and $200 \mathrm{~N}$ units fertilizer were the agronomic practices most appropriate for establishing sport field turfgrass, in substrate with about $75 \%$ of sand content, and allow an ecological turfgrass communities utilization able to sustain photosynthetic activity to reduce pollution in towns in environments with a Mediterranean climate.
Acknowledgements: The author expresses appreciation and thanks to the technician E. D'Andrea for technical assistance given in the experimental field during the evaluation of the experiment. The research was funded by the special project "Inerbimenti e tappeti erbosi per la valorizzazione agricola, ricreativa e sportiva del territorio" of the Ministry of Agricultural and Forestry Policy. Paper No. 158.

\section{REFERENCES}

Beard J.B. (1973) Turfgrass: Science and culture, Prentice-Hall, Inc., Englewood Cliffs, New Jersey, USA.

Canaway P.M. (1976) A differential-slip wear machine (D.S.1) for the artificial simulation of turfgrass wear, J. Sports Turf Res. Institute $52,92-99$.

Carrow R.N., Petrovic A.M. (1992) Effects of traffic on turfgrass, in: Waddington D.V., Carrow R.N., Shearman R.C. (Eds.), Turfgrass. Monograph 32, American Soc. of Agron. Madison, WI, USA, pp. 285-330.

Ferguson G.A., Pepper I.L. (1987) Ammonium retention in sand amended with clinoptilolite, Soil Sci. Soc. Am. J. 51, 231-234.

Ferguson G.A., Pepper I.L., Kneebone W.R. (1986) Growth of creeping bentgrass on a new medium for turfgrass growth: Clinoptilolite zeolite-amended sand, Agron. J. 78, 1095-1098.

Huang Z.T., Petrovic M. (1995) Physical properties of sand as affected by clinoptilolite zeolite particle size and quality, J. Turf. Mgmt. 1, $1-15$.

Huang B., Fu J. (2001) Growth and physical responses of tall fescue to surface soil drying, Int. Turfgrass Res. J. 9, 291-296.

Joo Y.K., Lee J.P., Christians N.E., Minner D.D. (2001) Modification of sand-based soil media with organic and inorganic soil amendments, Int. Turfgrass Res. J. 9, 525-531.

Ledeboer F.B., Skogely C.R. (1973) Effects of various nitrogen sources, timing, and rates on quality and growth rate of cool-season turfgrass, Agron. J. 65, 243-246.

Li D., Joo Y.K., Christians N.E., Minner D.D. (2000) Inorganic soil amendment effects on sand-based sports turf media, Crop Sci. 40, $1121-1125$.

Martiniello P. (2001) Valorizzazione agronomica delle risorse ambientali degli areali meridionali, Ambiente Risorse e Salute 20, 19-23.

McCoy E.L. (1998) Sand and organic amendment influences on soil physical properties related to turf establishment, Agron. J. 90, 411-419.

McCoy E.L., Stehouwer R.C. (1998) Water and nutrient retention properties of internally porous inorganic amendments in high sand content root zones, J. Turf. Mgmt. 2, 49-69.

Miltner E.D., Branham B.E., Paul E.A., Rieke P.E. (1996) Leaching and mass balance of ${ }^{15} \mathrm{~N}$-labeled urea applied to a Kentucky bluegrass turf, Crop Sci. 36, 1427-1433.

Miltner E.D, Stahanke G.K., Backman P.A. (2001) Leaf tissue content and soil $\mathrm{N}$ status following monthly applications of nitrogen fertilizer to fairway turf, Int. Turfgrass Res. J. 9, 409-415.

O’Neil K.H., Carrow R.N. (1983) Kentucky bluegrass growth and water use under different soil compaction and irrigation regimes, Agron. J. 74, 933-936.

Oral N., Açýkgöz E. (2001) Turf performances of cultivar blends with pure cultivars in four tufgrass species, Int. Turfgrass Res. J. 9, 892896.

Petrovic A.M., Wasiura J., Metler C. (1997) Physical stability of root zone amendments for sports fields, in: Cornell Turfgrass, Annual Report 1996, 1997, pp. 37-39. 
Russi L., Annicchiarico P., Martiniello P., Tomasoni C., Piano E., Veronesi F. (2004) Turf quality and reliability in varieties of four turfgrass species in contrasting Italian environments, Grass Forage Sci. 59, 233-239.

Shearman R.C., Carrow R.N., Wit L.A., Duncan R.R., Trenholm L.E., Worley J.E. (2001) Turfgrass traffic simulators: a description of two self-propelled devices simulating wear and compaction stress injury, Int. Turfgrass Res. J. 9, 347-352.

Steel R.G.D., Torrie J.H. (1980) Principles and procedures of statistics. A biometrical approach, 2nd ed., McGraw-Hill, Book Company, New York, USA.

Trenholm L.E., Duncan R.R., Carrow R.N. (1999) Wear tolerance, shoot performance, and spectral reflectance of seashore paspalum and bermudagrass, Crop Sci. 39, 1147-1152.

Turgeon A.J. (1999) Turfgrass management, 5th ed., Prentice-Hall, Upper saddle River, New Jersey, USA.

Vengris J., Torello W.A. (1982) Maintenance of fine turf areas, Thomson Pub. California, USA.

Voigt T.B., Fermanian T.W., Haley J.E. (2001) Influence of mowing and nitrogen fertility on tall fescue turf, Int. Turfgrass Res. J. 9, $953-$ 956.
Waddington D.V., Carrow R.N., Shearman R.C. (1992) Soils, soil mixtures and soil amendments, in: Mickelson S.H. (Ed.), Turfgrass. ASA, Madison, WI, USA, pp. 331-383.

Waddington D.V., Zimmerman T.L., Shoop G.J., Kardos L.T., Duich J.M. (1974) Soil modification for turfgrass areas. I. Physical properties of physically amended soil, Penn. Agri. Experiment Station Progress Report 337, University Park, PA, USA.

Watschke T.L., Schmidt R.E. (1992) Ecological aspects of turf communities, in: Waddington D.V., Carrow R.N., Shearman R.C. (Eds.), Turfgrass. Monograph 32, American Soc. of Agron. Madison, WI, USA, pp. 129-274.

Wilkinson J.F., Duff D.T. (1972) Effects of fall fertilization on cold resistance, colour, and growth of Kentucky bluegrass, Agron. J. 64, $345-348$

Wehner D.J., Haley J.E., Martin D.L. (1988) Late fall fertilization of Kentucky bluegrass, Agron. J. 80, 466-471.

Wilkinson J.F., Duff D.T. (1972) Effects of fall fertilization on cold resistance, colour, and growth of Kentucky bluegrass, Agron. J. 64, $345-348$. 